\title{
Inhibitory effects of four typical bloom-forming algae species on metamorphosis of the abalone Haliotis discus hannai
}

\author{
Xiaodong $\mathrm{Li}^{1,5,6, *}$, Tengfei Zhang ${ }^{1,6, *}$, Xiao Liu $^{2,4}$, Tian Yan ${ }^{1,3,4, * *}$, Rencheng Yu ${ }^{1,3,4}$, \\ Mingjiang Zhou ${ }^{1}$
}

${ }^{1}$ Key Laboratory of Marine Ecology and Environmental Sciences, Institute of Oceanology, Chinese Academy of Sciences, Qingdao 266071, PR China

${ }^{2}$ Key Laboratory of Experimental Marine Biology, Institute of Oceanology, Chinese Academy of Sciences, Qingdao 266071, PR China

${ }^{3}$ Laboratory for Marine Ecology and Environmental Science, Qingdao National Laboratory for Marine Science and Technology, Qingdao 266071, PR China

${ }^{4}$ Center for Ocean Mega-Science, Chinese Academy of Sciences, Qingdao 266071, PR China

${ }^{5}$ Present address: Fujian Agriculture and Forestry University, Fuzhou 350002, PR China

${ }^{6}$ Present address: University of Chinese Academy of Sciences, Beijing 100049, PR China

\begin{abstract}
In recent years, harmful algal blooms (HABs) have occurred frequently along the coast of China and have caused massive shellfish mortality. However, little is known about the impacts of HABs on the metamorphosis of shellfish. In this study, the effects of 4 typical harmful algae species present in Chinese waters (Karenia mikimotoi, Alexandrium catenella, Aureococcus anophagefferens, and Prorocentrum donghaiense) on the survival and metamorphosis of abalone Haliotis discus hannai larvae were investigated. After $96 \mathrm{~h}$ of treatment, un-metamorphosed larvae (veligers) were significantly affected by $K$. mikimotoi, $A$. catenella, and $P$. donghaiense, as mean \pm SD survival rates were $5.2 \pm 2.1,27.7 \pm 1.4$, and $63.8 \pm 6.9 \%$, respectively, compared with $86.0 \pm 4.1 \%$ for the control treatment (the non-toxic alga Skeletonema costatum). Survival rates of metamorphosed larvae were significantly affected by K. mikimotoi, A. catenella, and A. anophagefferens $(4.5 \pm 2.8,22.3 \pm 5.8$, and $26.5 \pm 3.6 \%$, respectively, compared with $46.2 \pm 1.3 \%$ for the control), and metamorphosis was significantly inhibited by K. mikimotoi and A. catenella ( $5.0 \pm 2.2$ and $24.5 \pm 3.1 \%$, respectively, compared with $49.3 \pm 1.5 \%$ for the control). A. anophagefferens was more toxic to metamorphosed larvae than to un-metamorphosed larvae. These results suggest that all 4 species of harmful algae have detrimental effects on the metamorphosis of $H$. discus hannai and that $K$. mikimotoi and A. catenella are more toxic to abalone larvae than A. anophagefferens and P. donghaiense.
\end{abstract}

KEY WORDS: Harmful algae $\cdot$ Haliotis discus hannai $\cdot$ Metamorphosis · Toxic impact

\section{INTRODUCTION}

In recent decades, harmful algal blooms (HABs) have occurred continuously in coastal waters of China, and are characterized by their high frequency

*These authors contributed equally to this manuscript

**Corresponding author: tianyan@qdio.ac.cn of occurrence, large scale, and diverse species (Yu et al. 2018). HABs have caused substantial financial losses to the marine aquaculture industry due to frequent mortalities of valuable fish and shellfish (Yu et al. 2018). For example, Karenia mikimotoi blooms

() The authors 2019. Open Access under Creative Commons by Attribution Licence. Use, distribution and reproduction are unrestricted. Authors and original publication must be credited. 
caused losses of more than 2 billion yuan (US \$290 million) to the abalone culture industry along the coast of Fujian Province in 2012 (Li et al. 2017). Aureococcus anophagefferens blooms were responsible for large-scale diapauses and mortalities of the bay scallop Argopecten irradians, which resulted in 200 million yuan (US $\$ 29$ million) in losses along the coast of Qinhuangdao in the Bohai Sea (Zhang et al. 2012). Annual Alexandrium spp. and Prorocentrum donghaiense blooms also threaten the local marine aquaculture industry in the Changjiang River estuary (Gu et al. 2013, Lin et al. 2014). Many harmful algae species are toxic to abalone, and they can damage tissues, affect immune activities, and impact survival rates (Botes et al. 2003, Shi et al. 2012, Lin et al. 2016a). However, the effects of harmful algae on metamorphosis, a critical process for larval abalone, have not been described.

Metamorphosis is a critical process in the life cycle of shellfish; it plays an important role in shellfish population dynamics and determines the success of their breeding in culture and reproduction in the wild (Burke 1983, Hadfield \& Paul 2001). Metamorphosis of both cultured and wild abalone in China occurs from April to July, which coincides with the period of high incidence of HABs. Moreover, the culture area for abalone in China is located mainly along the coast of the Bohai Sea and the East China Sea, where HABs occur frequently every year (Yu et al. 2018). HABs may inhibit activity of shellfish larvae or cause direct shellfish larval mortality (Tang \& Gobler 2012, Basti et al. 2015a,b). Therefore, HABs can be a great threat to metamorphosis of both cultured and wild abalone.

To explore whether and how harmful algae species affect metamorphosis of abalone Haliotis discus hannai, 4 typical species present in Chinese waters (K. mikimotoi, Alexandrium catenella, Aureococcus anophagefferens, and $P$. donghaiense) were selected and their effects on survival and metamorphosis of abalone at the late veliger to peristome larval stages examined. Non-toxic Skeletonema costatum served as the control algal species.

\section{MATERIALS AND METHODS}

Abalone larvae were maintained in corrugated plastic plates, with diatoms as the food source. All test algae were isolated from coastal waters of China and cultured in IOCAS with sterilized f/2 seawater medium (Guillard \& Ryther 1962) at a temperature of $20 \pm 1^{\circ} \mathrm{C}, \mathrm{pH}$ of $8.09 \pm 0.05$, and salinity of
$30 \pm 1$ ppt. Cultures were kept under a $12: 12 \mathrm{~h}$ photoperiod using cool-white fluorescent lamps $(2650 \pm 100$ Lux $)$.

The corrugated plates were cut and transferred into plastic petri dishes $(9 \mathrm{~cm}$ diameter). Late veliger stage abalone larvae were counted under a dissecting scope, and 200 individuals were added to each dish. Algae were counted using a hemocytometer under a microscope and diluted to $60 \mathrm{ml}$ at different densities (Karenia mikimotoi, Alexandrium catenella, Aureococcus anophagefferens, Prorocentrum donghaiense, and Skeletonema costatum at $5 \times 10^{3}, 4 \times 10^{3}, 1 \times 10^{7}, 4.4 \times 10^{4}$, and $2.3 \times 10^{5}$ cells ml $^{-1}$, respectively). The density of $K$. mikimotoi was chosen as the common bloom density along the coast of China, and the densities of the other algae were set based on their cell size to create a biomass equal to that of K. mikimotoi; these densities were also roughly similar to their common bloom densities. The non-toxic alga $S$. costatum served as the control, as this species is not directly toxic, especially at a low density (Lin et al. 2016b), and seawater alone was used as the blank. Each treatment was replicated 3 times.

All larvae were observed under a microscope after $96 \mathrm{~h}$. Those individuals showing no stress reaction (i.e. no movement in response to stimulation with a needle) were considered to be dead, and those with a shell were considered to have metamorphosed. Mortality was calculated as the total percentage of individuals that died, and total metamorphosis was calculated as the percentage of all larvae that had metamorphosed. Final metamorphosis totals were calculated as the percentage of metamorphosed individuals that survived. Experimental data were analyzed using 1-way ANOVA followed by a Dunnett's test, and tests were conducted using SPSS 19.0. Sample differences were considered to be statistically significant at $\mathrm{p}<0.05$ and highly significant at $\mathrm{p}<$ 0.01 . Values are presented as means $\pm \mathrm{SD}$.

\section{RESULTS}

After $96 \mathrm{~h}$ of incubation, both survival and metamorphosis of Haliotis discus hannai were influenced by all 4 algae tested. Final metamorphosis was significantly inhibited (ANOVA, $F_{5,12}=$ 111.27, p < 0.01) by Karenia mikimotoi, Alexandrium catenella, and Aureococcus anophagefferens (Fig. 1). Percentage of surviving metamorphosed individuals in the $K$. mikimotoi treatment was the lowest $(4.5 \pm 2.8 \%)$, followed by the A. catenella 


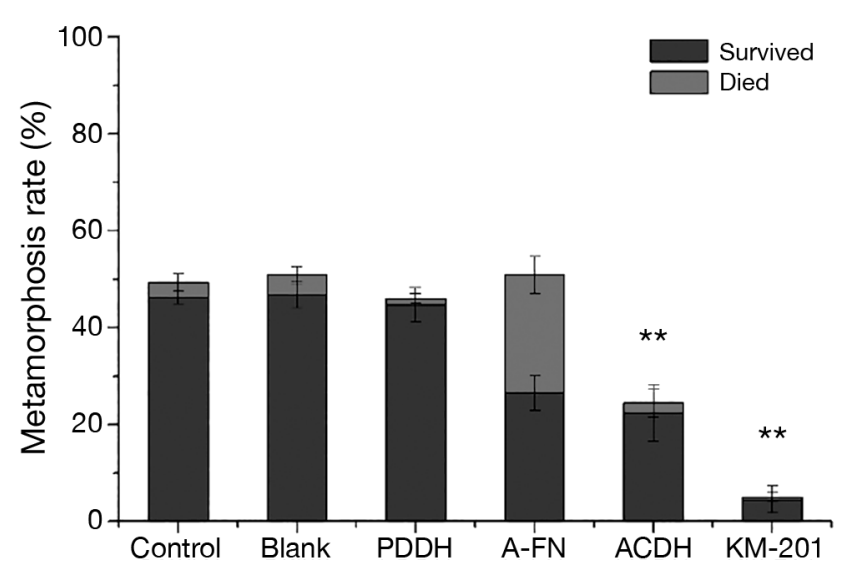

Fig. 1. Mean percentage of live and dead abalone Haliotis discus hannai larvae which had metamorphosed at $96 \mathrm{~h}$ when treated with Karenia mikimotoi (IOCAS code: KM-201), Alexandrium catenella (ACDH), Prorocentrum donghaiense (PDDH), and Aurecoccus anophageffrens (A-FN). Vertical bars represent SD and asterisks denote significant differences in total metamorphosis from controls $\left({ }^{*} \mathrm{p}<0.05,{ }^{* *} \mathrm{p}<\right.$ $0.01)$. Control treatments included the non-toxic alga Skeletonema costatum; blanks consisted of seawater alone

$(22.3 \pm 5.8 \%)$ and A. anophagefferens $(26.5 \pm$ $3.6 \%)$ treatments.

Both $K$. mikimotoi and A. catenella significantly inhibited total metamorphosis after $96 \mathrm{~h}(5.0 \pm 2.2$ and $24.5 \pm 3.1 \%$, respectively; p $<0.01$; Fig. 1). In contrast, total metamorphosis in the $A$. anophagefferens and Prorocentrum donghaiense treatments (50.8 \pm 4.9 and $46 \pm 4.0 \%$, respectively) did not differ significantly from that observed for the control treatment $(49.3 \pm 1.5 \%)$.

All test algae species were significantly lethal to abalone larvae (ANOVA, $F_{5,12}=89.69, \mathrm{p}<0.01$; Fig. 2). Total mortalities in the K. mikimotoi, $A$. catenella, $A$. anophagefferens, and $P$. donghaiense treatments were $95.3 \pm 2.8,74.5 \pm 2.8,48.5 \pm 12.1$, and $37.5 \pm 6.4 \%$, respectively, compared with $17.2 \pm$ $3.1 \%$ for the control. However, different algae species had different effects on larvae at different stages. K. mikimotoi, A. catenella, and P. donghaiense were toxic to abalone larvae at the late veliger stage. Compared with the control $(14.0 \pm 4.1 \%)$, veliger mortality rates in these 3 treatments were significantly higher $\left(\right.$ ANOVA, $\left.F_{5,12}=143.83, \mathrm{p}<0.01\right)$, at $94.8 \pm$ $2.1,72.3 \pm 1.4$, and $36.2 \pm 6.9 \%$, respectively. However, A. anophagefferens was more toxic to metamorphosed larvae (larvae with a peristome) than to late veliger stage larvae, as $24.3 \pm 3.9 \%$ of metamorphosed larvae died after $96 \mathrm{~h}$ of treatment with $A$. anophagefferens (which was nearly half of total metamorphosed individuals).

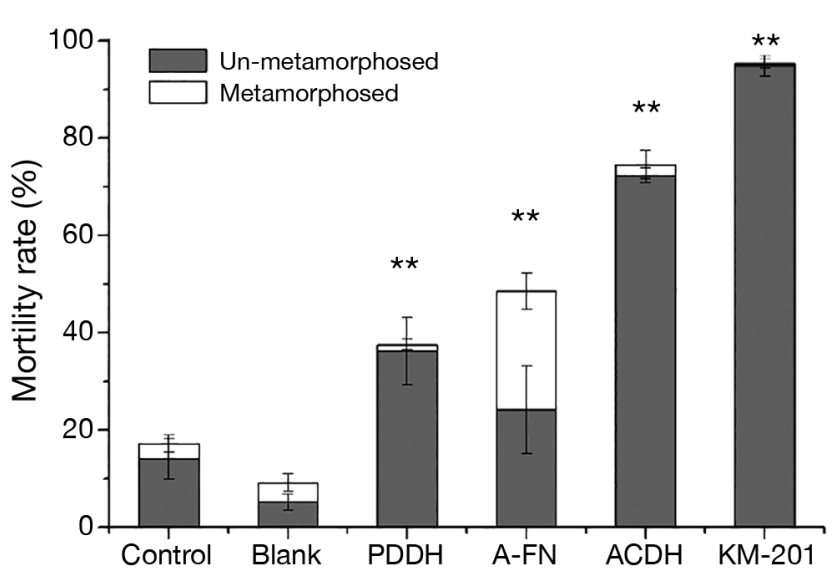

Fig. 2. Mean percentage of metamorphosed and unmetamorphosed abalone Haliotis discus hannai larvae which had been killed at $96 \mathrm{~h}$ when treated with toxic algae. Vertical bars represent SD and asterisks denote significant differences in mortality from controls. See Fig. 1 for further details

\section{DISCUSSION}

Although our results suggested that all 4 selected algae have negative impacts on abalone, they also clearly demonstrated that responses varied among algal species. The effects of Karenia mikimotoi and Alexandrium catenella on abalone larvae were similar; both were extremely lethal to un-metamorphosed larvae, and they were the only 2 species that significantly inhibited metamorphosis. K. mikimotoi is cytotoxic, hemolytic, and ichthyotoxic, and it can cause mortality to many fish, shellfish, and other invertebrate species (Cross \& Southgate 1980, Botes et al. 2003, Silke et al. 2005, Mitchell \& Rodger 2007, Li et al. 2017). A. catenella can produce paralytic shellfish poisoning toxin, and is also lethal to fish and invertebrates (Chen et al. 2007a,b). Both species can cause veliger larvae to die before metamorphosis begins (Shumway \& Cucci 1987, Mu \& Li 2013). Basti et al. (2015a) also found that they significantly inhibited activity of the Japanese pearl oyster Pinctada fucata martensii larvae at low densities (500 cells $\left.\mathrm{ml}^{-1}\right)$; however, no lethal effect was observed, which indicates that algal toxicity may be species specific.

Aureococcus anophagefferens did not affect metamorphosis, but was toxic to metamorphosed larvae, suggesting that algal toxicity changes with abalone ingestion method pre and post metamorphosis. A. anophagefferens inhibits ingestion rates in many copepods and shellfish, and causes mortality (Greenfield \& Lonsdale 2002, Caron et al. 2004, Padilla et al. 2006, Bricelj \& MacQuarrie 2007). During metamorphosis, feeding processes change from lecithotrophic 
at the veliger stage to heterotrophic after metamorphosis when they ingest primarily diatoms (Ino 1952). A. anophagefferens may affect mortality of metamorphosed larvae by inhibiting ingestion, which explains why the percentage of dead metamorphosed individuals was higher in this treatment than in the others.

Prorocentrum donghaiense had no significant effects on total metamorphosis or final survival, but it was toxic to veliger larvae. $P$. donghaiense is generally considered to be a nontoxic species because no known toxin has been detected. However, it does have impacts on survival of some zooplankton species, such as brine shrimp Artemia salina and copepods (Moina mongolica; Chen et al. 2007a), and on the life cycle of rotifers (Brachionus plicatilis; Lin et al. 2016b). In the present study, $P$. donghaiense was toxic to abalone larvae, as it reduced the number of veligers, which may have effects on the population.

Metamorphosis is a crucial period in the life cycle of abalone. During this process, the ingestion method, body structures, physiological functions, and behavior change drastically within a short period of time, and this process can be affected by changing environmental parameters such as temperature, salinity, and substrate (Wang et al. 2006). During the veliger stage, abalone larvae do not have a shell, which means that they are fragile and susceptible to toxic algae by direct contact (Botes et al. 2003, Basti et al. 2015a). Basti et al. (2015a) suggested that presettling larvae of Pinctada fucata martensii were more sensitive to these same 4 harmful algae than were D-stage larvae. In our study, we observed mortality of abalone veliger larvae exposed to K. mikimotoi, A. catenella, and P. donghaiense. In contrast, metamorphosed individuals at the peristome stage, which are protected by a shell, are much more tolerant to toxic algae. However, the change in nutritional mode from autotrophic to heterotrophic in metamorphosed larvae made them more susceptible to $A$. anophagefferens, suggesting that it might inhibit ingestion after metamorphosis.

All 4 selected algae are typical and common bloom-forming species in coastal waters of China, including the Bohai Sea, northern Yellow Sea, and East China Sea, and have caused direct shellfish mortality in most abalone, but also in clam and scallop farms, in this region ( $\mathrm{Yu}$ et al. 2018). Our results suggest that these algae may also further harm abalone by inhibiting metamorphosis. Compared with mature individuals, abalone larvae were more sensitive to harmful algae, especially to toxic species like $K$. mikimotoi and A. catenella, because signifi- cant mortality and inhibition were observed at a lower density than that observed in HABs (Botes et al. 2003, Lin et al. 2016a). Inhibition of ingestion by A. anophagefferens also caused heavy post-metamorphic damage to abalone larvae. Culture of shellfish larvae including abalone could thus collapse when toxic algae bloom nearby or when the algae are pumped with water into indoor breeding pools. Even algae like $P$. donghaiense, which was previously reported to be non-toxic, may have long-term effects on wild abalone populations. Thus, these HAB-forming species should be considered harmful to shellfish farms, including abalone and shellfish breeding ponds, as well as fish farms.

Acknowledgements. This work was supported by the Science \& Technology Basic Resources Investigation Program of China (2018FY100206), the National Nature Science Foundation of China (NSFC 41476102 and U1406403), the National Marine Laboratory Key Program (2015ASKJ02), and the Sino-Australian Centre for Healthy Coasts (2016YFE0101500). Karenia mikimotoi was kindly provided by Dr. Dazhi Wang from Xiamen University. Abalone specimens were kindly provided by Prof. Xiao Liu from the Institute of Oceanology, Chinese Academy of Sciences (IOCAS), and raised with the help of Chen Yan from IOCAS. We are grateful to the anonymous reviewers and the Editor for their valuable comments that resulted in an improvement of this manuscript.

\section{LITERATURE CITED}

Basti L, Nagai S, Go J, Okano S and others (2015a) Differential inimical effects of Alexandrium spp. and Karenia spp. on cleavage, hatching, and two larval stages of Japanese pearl oyster Pinctada fucata martensii. Harmful Algae 43:1-12

Basti L, Nagai S, Nagai K, Go J and others (2015b) Harmful algal blooms affect early-life stages of Japanese pearl oyster, Pinctada fucata martensii. In: Mackenzie AL (ed) Marine and freshwater harmful algae. Proceedings of the 16th International Conference on Harmful Algae, Wellington, New Zealand. Cawthron Institute, Nelson, p 94-97

Botes L, Smit A, Cook PA (2003) The potential threat of algal blooms to the abalone (Haliotis midae) mariculture industry situated around the South African coast. Harmful Algae 2:247-259

Bricelj VM, MacQuarrie SP (2007) Effects of brown tide (Aureococcus anophagefferens) on hard clam Mercenaria mercenaria larvae and implications for benthic recruitment. Mar Ecol Prog Ser 331:147-159

* Burke RD (1983) The induction of metamorphosis of marine invertebrate larvae: stimulus and response. Can J Zool 61:1701-1719

Caron DA, Gobler CJ, Lonsdale DJ, Cerrato RM and others (2004) Microbial herbivory on the brown tide alga, Aureococcus anophagefferens: results from natural ecosystems, mesocosms and laboratory experiments. Harmful Algae 3:439-457 
Chen TY, Tian Y, Liping WP, Bin Z, Mingjiang ZJ (2007a) The effect of the causative algae of large-scale HAB in the East China Sea on egg hatching of Argopecten irradians, and population growth of Brachionus plicatilis and Moina mongolica. Acta Oceanol Sin 26:112-122

Chen TY, Yan T, Tan ZJ, Wang LP, Zhou MJ (2007b) Toxicity of dinoflagellate Alexandrium species. Oceanol Limnol Sin 38:55-61

* Cross TF, Southgate T (1980) Mortalities of fauna of rocky substrates in southwest Ireland associated with the occurrence of Gyrodinium aureolum blooms during autumn 1979. J Mar Biol Assoc UK 60:1071-1073

Greenfield DI, Lonsdale DJ (2002) Mortality and growth of juvenile hard clams Mercenaria mercenaria during brown tide. Mar Biol 141:1045-1050

Gu H, Zeng N, Liu T, Yang W, Müller A, Krock B (2013) Morphology, toxicity, and phylogeny of Alexandrium (Dinophyceae) species along the coast of China. Harmful Algae 27:68-81

Guillard RR, Ryther JH (1962) Studies of marine planktonic diatoms. I. Cyclotella nana Hustedt and Detonula confervacea (Cleve) Gran. Can J Microbiol 8:229-239

Hadfield MG, Paul VJ (2001) Natural chemical cues for settlement and metamorphosis of marine invertebrate larvae. In: McClintock JB, Baker BJ (eds) Marine chemical ecology. CRC Press, Boca Raton, FL, p 431-461

Ino T (1952) Biological study on the propagation of Japanese abalone (genus Haliotis). Bull Tokai Reg Fish Res Lab 5: $1-102$

Ki XD, Yan T, Lin JN, Yu RC, Zhou MJ (2017) Detrimental impacts of the dinoflagellate Karenia mikimotoi in Fujian coastal waters on typical marine organisms. Harmful Algae 61:1-12

Lin JN, Yan T, Zhang QC, Wang YF, Liu Q, Zhou MJ (2014) In situ detrimental impacts of Prorocentrum donghaiense blooms on zooplankton in the East China Sea. Mar Pollut Bull 88:302-310

Lin JN, Yan T, Zhang QC, Wang YF, Liu Q, Zhou MJ (2016a) Effects of Karenia mikimotoi blooms on antioxidant enzymes in gastropod abalone, Haliotis discus hannai. Mark Sci 40:17-22

Lin JN, Yan T, Zhang QC, Zhou MJ (2016b) Impact of several

Editorial responsibility: Brett Dumbauld,

Newport, Oregon, USA harmful algal bloom (HAB) causing species, on life history characteristics of rotifer Brachionus plicatilis Müller. Chin J Oceanol Limnol 34:642-653

Mitchell S, Rodger H (2007) Pathology of wild and cultured fish affected by a Karenia mikimotoi bloom in Ireland, 2005. Bull Eur Assoc Fish Pathol 27:39-42

$\mathrm{Mu}$ CM, Li Q (2013) Effects of the dinoflagellate Alexandrium catenella on the early development of the Pacific oyster Crassostrea gigas. J Shellfish Res 32:689-694

*Padilla DK, Doall MH, Gobler CJ, Hartson A, O'Boyle K (2006) Brown tide alga, Aureococcus anophagefferens, can affect growth but not survivorship of Mercenaria mercenaria larvae. Harmful Algae 5:736-748

Shi F, McNabb P, Rhodes L, Holland P and others (2012) The toxic effects of three dinoflagellate species from the genus Karenia on invertebrate larvae and finfish. NZ J Mar Freshw Res 46:149-165

* Shumway SE, Cucci TL (1987) The effects of the toxic dinoflagellate Protogonyaulax tamarensis on the feeding and behaviour of bivalve molluscs. Aquat Toxicol 10:9-27

Silke J, O'Beirn FX, Cronin M (2005) Karenia mikimotoi: an exceptional dinoflagellate bloom in western Irish waters, summer 2005. Marine Environment and Health Series No. 21. Marine Institute, Marine Environment and Food Safety Services, Galway

Tang YZ, Gobler CJ (2012) Lethal effects of Northwest Atlantic Ocean isolates of the dinoflagellate, Scrippsiella trochoidea, on Eastern oyster (Crassostrea virginica) and Northern quahog (Mercenaria mercenaria) larvae. Mar Biol 159:199-210

Wang J, Cong W, Zhang J, Wang, W and others (2006) Effect of environmental factors on the attachment and metamorphosis of abalone. Fish Moder 3:38-40 (in Chinese)

Yu RC, Lü SH, Liang YB (2018) Harmful algal blooms in the coastal waters of China. In: Glibert PM, Berdalet E, Burford MA, Pitcher GC, Zhou M (eds) Global ecology and oceanography of harmful algal blooms. Springer International Publishing, Cham, p 309-316

* Zhang QC, Qiu LM, Yu RC, Kong FZ and others (2012) Emergence of brown tides caused by Aureococcus anophagefferens Hargraves et Sieburth in China. Harmful Algae 19:117-124

Submitted: February 25, 2019; Accepted: August 10, 2019

Proofs received from author(s): November 11, 2019 